\title{
Seedling emergence and survival of invasive pines in Argentinian mountain grasslands
}

\author{
Gabriela I. E. Brancatelli 1 - Martín R. Amodeo $(\mathbb{D} \cdot$ Sergio M. Zalba
}

Received: 19 August 2020/Accepted: 28 October 2020/Published online: 23 November 2020

(C) Springer Nature Switzerland AG 2020

\begin{abstract}
Natural regeneration is a critical step for the dispersal of alien plants and the establishment of new invasive foci. The adequate timing and location of germination, as well as the survival of the seedlings, have direct effects on the recruitment of the population, and are expected to depend on habitat characteristics. Understanding the dynamics of these processes, and their variations according to the landscape at different scales, can be particularly important to design and implement control strategies. In this article, we evaluate differences in seedling emergence and establishment of Pinus halepensis in highland grasslands of the Argentine pampas, according to altitude, orientation of the slope and vegetation cover. Our results showed spatial variation on the rate of seedling emergence, with topography as a determining factor, possibly due to a facilitating effect on the slopes with higher incident solar radiation (NE at the study site). Slope exposition, on the contrary, seemed to have the opposite effect on the survival of seedlings. Once
\end{abstract}

Electronic supplementary material The online version of this article (https://doi.org/10.1007/s10530-020-02410-6) contains supplementary material, which is available to authorized users.

G. I. E. Brancatelli ( $\square)$ - M. R. Amodeo · S. M. Zalba GEKKO, Grupo de Estudios en Conservación y Manejo, Departamento de Biología, Bioquímica y Farmacia, Universidad Nacional del Sur, San Juan 670 (8000), Bahía Blanca, Argentina

e-mail: gabriela.brancatelli@uns.edu.ar established, seedlings also survived better in sites with less solar exposure, probably due to protection from high evapotranspiration during the summer. These results could explain variations in the invasive performance of the species and guide management actions aimed at preventing its further expansion in the study area and in other habitats with similar characteristics.

Keywords Invasive alien species - Pine invasion · Germination $\cdot$ Seedling emergence $\cdot$ Seedling survival $\cdot$ Management

\section{Introduction}

Invasive alien species are considered one of the main global threats to biodiversity (Lövei and Lewinsohn 2012; Simberloff et al. 2013; Alexander et al. 2014). Woody plant invasions, in particular, have the ability to dominate the landscape and dramatically change the dynamics of grassland ecosystems (Williams and Wardle 2005). Several species of the Pinaceae family (hereafter Pines), almost exclusively native to the northern hemisphere, have been introduced and planted in different regions of the southern hemisphere for commercial exploitation, landscaping and control of soil erosion, and many of them have become invasive (Richardson and Higgins 2000; Simberloff 
et al. 2010). Pines can change the dominant life forms, increase biomass, thus modifying the frequency and intensity of the fires (Richardson 1998; Taylor et al. 2017), alter hydrological regimes (Gorgens and Van Wilgen 2004; Jobbágy et al. 2013) and change soil properties, as well as the availability and flow of nutrients in the ecosystem (Jobbágy and Jackson 2003; Amiotti et al. 2007; Dickie et al. 2014).

Natural regeneration is a key process in the population dynamics of plant species (Manso et al. 2013), and thus, a critical step in the dispersal and establishment of invasive plants. Seed germination represents a risky transition from a stage that is more tolerant to environmental conditions to the weakest and most vulnerable stage in plant development, the seedling (Harper 1977; Baskin and Baskin 2014). As it is also an irreversible process, the adequate timing and location of germination has a direct impact on the recruitment of the population (Baskin and Baskin 2014). Seeds are dispersed to a variety of microhabitats with a range of different biotic and abiotic conditions that affect seed germination, emergence, survival and growth of seedlings. Recruitment may be limited by different reasons, including the efficiency of seed dispersal, seed predation, abiotic stresses such as drought and light limitations, and availability of suitable microsites for seed germination and establishment of seedlings (Retana et al. 1999). In plant species with wide geographical distributions, the different populations are usually subject to different environmental conditions, and therefore to environments with diverse ecological constraints (Castro et al. 2004), which a priori could result in a greater diversity of capacities and colonization strategies and, consequently, in a greater aptitude to become established and to invade new environments.

Pine recruitment could be strongly influenced by the interaction between the seedlings and the resident vegetation (Richardson and Bond 1991; Langdon et al. 2019). The quality of the habitat at the local level can be a determining factor for both germination and establishment (Castro et al. 2005; Del Campo et al. 2007). Simberloff et al. (2010) highlight the importance of propagule pressure to define the fate of the colonization process in conifers. The discussion about the availability of seeds versus that of appropriate microsites as determinants for plant establishment is not new, and the combined limitation of both factors could be particularly significant for the regulation of recruitment in plant populations (Eriksson and Ehrlén 1992; Turnbull et al. 2000). Pines usually produce large amounts of seed (Richardson and Rundel 1998), and therefore the availability of propagules is usually not a limiting factor. Thus, understanding the effects of the characteristics of the seed arrival sites on their germination and on seedling survival would be particularly important for the establishment of new foci of invasion.

The Pampas biome is one of the most intensely affected by human activities in South America. Due to its mild climate and the aptitude of the soils, it has been historically used for agriculture and livestock husbandry (Bilenca and Miñarro 2004; Fonseca et al. 2013; Pretelli et al. 2015). Many of the valuable remaining grassland in the region have been invaded by pine trees (Pinus halepensis, $P$. radiata, $P$. pinaster and $P$. elliottii, among others) dispersed from nearby cultivated areas (Zalba and Villamil 2002; Yezzi et al. 2018). The Ventania mountains, at the southern tip of the South American Pampas, constitute a particularly valuable relict, where the rocky outcrops prevented the advance of the agricultural frontier. The area, however, undergoes an intense process of colonization by invasive woody plants, especially Aleppo pine (Pinus halepensis, Zalba and Villamil 2002). Aleppo pines, a native species of the Mediterranean basin, are capable of growing in the full height range and respond positively to the two main structuring forces of grassland plant communities, fire and herbivory, thus representing the main threat to the conservation of this refuge for the regional biodiversity (Zalba et al. 2008; de Villalobos and Zalba 2010; de Villalobos et al. 2011).

Knowing the specific characteristics of favorable sites for pine recruitment can help in the development of more effective management actions by mapping particularly suitable areas for the establishment of pine trees, and thus identifying sites where to intensify the search for new sources of invasion and targeting associated seed sources for elimination, according to the direction of the prevailing winds (Brancatelli and Zalba 2018).

One of the main forces regulating the growth of Aleppo pines (Pinus halepensis) in their native range is the availability of water (Rathgeber et al. 2005; Olivar et al. 2012, 2014; Bueis et al. 2017). The correlation between precipitation and growth of this species is usually significant and positive (Condés and 
García-Robredo 2012). Therefore, topography at the local level is relevant since it partially regulates water flows as well as soil characteristics that affect its availability by plants (Vennetier et al. 2018). In Jordan, Omary (2011) found differential growth of Aleppo pines according to the orientation of the slopes where they were growing that could be attributed to local differences in rainfall. Del Río et al. (2008), in Spain, indicated higher recruitment on sunny slopes than in shady areas. Nevertheless, high temperatures cause greater evapotranspiration resulting in water stress on seedlings (Condés and García-Robredo 2012). Consistently, summer time, associated with high temperatures and marked drought, constitutes the phase of greatest risk for newly emerged seedlings in the region where the species is native (Rathgeber et al. 2005; Del Río et al. 2008; Papadopoulos et al. 2009). The first summer is estimated to be the period of greatest mortality for the species (Thanos et al. 1996). Another important factor that affects establishment in $P$. halepensis is the interaction with the surrounding vegetation (Richardson and Bond 1991). Competition with abundant herbaceous cover can result in a high recruitment failure rate (Rubira et al. 1996; Puértolas et al. 2003). However, bare soil seems not to be beneficial either (Gasque and García-Fayos 2004). Climate, topography and the regime of disturbances particularly affect the recruitment of pines and their capacity to invade natural ecosystems in mountain ranges (Mast et al. 1997; Ayari et al. 2011), by affecting their development, fecundity and dispersal (Vennetier et al. 2018). A previous study in our area showed differences in growth rate, as well as in the age at maturity of Aleppo pines growing in peaks, compared to those growing on hillsides and valleys (Brancatelli et al. 2020), while the effect of environmental variables on the germination and establishment of this invasive species was unknown until this publication.

The objective of this study is to evaluate differences in seedling emergence and establishment of Pinus halepensis in highland grasslands of the Argentine pampas, according to altitude, orientation of the slope and vegetation cover. We expect to find a better performance both in seedling emergence, survival and growth on the NE side of the mountains, where a higher average annual precipitation coincides with more sunny hillsides (Gentili and Gil 2013). At high altitudes (900-1200 m a.s.1.), a decrease in emergency and establishment can be expected due to environmental stress caused by low temperatures and exposure to stronger winds (Kristensen and Frangi 1995a, 1996). At the same time, recruitment is expected to be more successful in sites with intermediate plant cover, since both extremes: bare soil (due to excess radiation, higher predation, etc.) and consolidated grassland vegetation (due to competition), limit survival and growth of seedlings (Zalba et al. 2008; de Villalobos et al. 2011).

\section{Materials and methods}

Study area

This study was carried out at the Ernesto Tornquist Provincial Park (ETPP) that covers an area of ca. 6700 hectares in the Ventania mountains $\left(38^{\circ} 10^{\prime} \mathrm{S}\right.$, $\left.62^{\circ} 8^{\prime} \mathrm{W}\right)$, Argentina, and includes natural grassland in a range that extends from basal valleys at $450 \mathrm{~m}$ a.s.l. to some of the highest peaks in the pampas region, which barely exceed $1200 \mathrm{~m}$ above sea level (Kristensen and Frangi 1995b).

The climate is temperate, with a mean annual temperature of $14.6^{\circ} \mathrm{C}$. Average annual rainfall ranges from 600 to $800 \mathrm{~mm}$, especially concentrated in spring and part of summer (Frangi and Botinno 1995). The mountain topography determines local variations of the climate based on altitude, exposure and slope (Kristensen and Frangi 1995b). Thus, for example, habitats at higher altitudes are characterized by a high evaporation, strong winds and shallow soils (Kristensen and Frangi 1996). The orientation of the slope determines the amount of sunshine it receives, being the south-west facing areas more shady, with lower evaporation and higher humidity; while the slopes to the northeast are sunny and warmer, and hence with higher evaporation. These conditions determine differences in the composition and the structure of vegetation (Kristensen and Frangi 1995b). The area belongs to the Southern District of the Pampas Phytogeographic Region, where grass steppe is the dominant vegetation (Cabrera 1976; Frangi and Botinno 1995; Long et al. 2004). Although the region was almost deprived of trees before European settlement (Parodi 1942), it is currently under an invasion process that quickly replaces the grassland ecosystem with monospecific pine stands 
(Pinus halepensis and $P$. radiata), among other invasive species (Zalba and Villamil 2002; Amodeo et al. 2017).

\section{Collection of seeds}

During the months of January and February 2018, twenty individuals growing at altitudes between 450 and $500 \mathrm{~m}$ a.s.l. were selected. Five full-grown but still closed cones were collected from each of them, all located at a height that facilitated extraction (less than $2.5 \mathrm{~m}$ ).Cones were placed near a heat source to promote their opening and the released seeds were kept in paper envelopes until the time of planting.

\section{Laboratory germination experiment}

Pinus halepensis seeds do not require stratification since they have an endogenous rhythm that regulates germination under the right conditions (Skordilis and Thanos 1995). To estimate the germination potential of the collected seeds, a test was carried out in a germination chamber using five Petri dishes with 20 seeds each (100 seeds in total), at constant humidity with a photoperiod of $13 \mathrm{~h}$ of light at $20^{\circ} \mathrm{C}$ and $11 \mathrm{~h}$ of darkness at $15{ }^{\circ} \mathrm{C}$ (optimal germination conditions for Aleppo pine, Skordilis and Thanos 1997). Germination was registered when a radicle of 5-10 $\mathrm{mm}$ long emerged.

\section{Irrigated experiment}

A control site was placed outdoors in the Pillahuincó Botanic Garden, located in a valley (460 m a.s.1.) of the ETPP. This site included five plots (of approximately $1 \mathrm{~m}^{2}$ each) with 40 seeds each, planted manually in small excavations of $1 \mathrm{~cm}$ depth covered by the substrate. Control plots received periodic irrigation (biweekly), in order to free them from water stress. The volume of water was calculated so that the sum of rainfall and irrigation reaches at least the monthly average rainfall according to the historical records in the area for the period 2000-2016 (Table S1 supplementary material, data provided by Ernesto Tornquist Provincial Park staff).
Field experiment

Twelve sampling sites were distributed on the two main orientations of the mountains: northeast and southwest; and at three different altitudes: low (450-500 m a.s.1.), mid (600-650 m a.s.1.) and high (900-950 $\mathrm{m}$ a.s.1.). This resulted in a crossed design between the two factors with two replicates for each combination. At each experimental site five plots of $1 \times 1 \mathrm{~m}$ were located randomly. In April 2018, 40 seeds per plot were planted in the same way as was done for those under control conditions. Seeds did not receive any previous treatment and individual planting sites were marked by labeled stakes. A total of 2600 seeds were sown and monitored every 2 weeks for a total period of 2 years, recording seedling emergence and mortality, and measuring their total longitude (from ground to the highest leaf).

Since it is estimated that $97 \%$ of the seeds produced by an adult individual are concentrated at less than $20 \mathrm{~m}$ from the tree (Nathan et al. 2000), each plot was located more than $30 \mathrm{~m}$ away from any adult pine in order to minimize the probability of arrival of exogenous seeds. Only some of the sites in the SW hillside had a few adult specimens of Aleppo pine about 50-150 m away. Most of the plots were located in sites with no pines in the surrounding areas (more than $200 \mathrm{~m}$ ).

Vegetation and rainfall were recorded at sampling sites every 2 months. Percentage cover of bare soil and rocks (BSR), grasses and herbs (GHR), and shrubs and subshrubs (SHR) was assessed in each plot. We also recorded the average height of the vegetation at five random points within each plot. A plastic rain gauge, with a wide mouth and $140 \mathrm{~mm}$ of total capacity, was placed at each site to assess local rainfall.

Statistical analyses

We analyzed seedling emergence and survival separately by means of time-to-event analyses (McNair et al. 2012). Since only two seedlings emerged during the second year, we only included data of the first year in the emergence analysis. Time since sowing and time since emergence were used as time scales for the analysis of emergence and survival, respectively. Seeds that did not germinate during the experiment were treated as censored data and they were given a censoring time (302 days) that was defined as the last 
day of the germination period, after which germination did not occur. The same was applied for seedling survival (699 days assigned for seeds that did not die during the whole experimental time). We compared seedling emergence and survival across the different slope orientations and altitudes using proportional hazards regressions (or Cox regressions). The Cox model is based on a hazard function defined by the product of a baseline hazard function that depends only on time, and a modifier function that depends on the covariates (McNair et al. 2012). No parametric assumptions are made about the baseline hazard function, while the covariate portion does depend on parameters. The hazard ratio obtained from this analysis represents the ratio of the intensity of emergence (or mortality) in two comparing groups. To account for random factors that arise from our experimental design (sites and plots), we incorporated a frailty term to the Cox regressions. Frailty terms are random effects allowing the emergence/survival rate to vary among these categories. The proportional hazards model assumes that the hazard ratio is constant with respect to time. We checked this assumption using graphical methods following McNair et al. (2012). Potential multicollinearity of the covariates was also assessed using variance inflation factor analysis (VIF). Neither of these evaluations showed clear violations of the model assumptions: no decisive crossings of the functions in the proportionality diagnostic plot were detected, and the analysis of VIF, showed no evidence of collinearity. For graphical representation we used KaplanMeier curves for showing the survival data and "1 minus Kaplan-Meier" curves for emergence data to show the proportion of seed that had germinated on any given day of the experiment (Andersen et al. 2016).

The length of the seedlings was compared among altitudes and orientations for measurements at their median age (140 days) using GLM with Gamma distribution and inverse link function, and Tukey post hoc comparisons. The distribution was chosen based on QQplots.

Temporal variation in microhabitat conditions across all sampling dates for each site was assessed using coefficients of variation at each site. Average values were compared between sites at different altitudes and orientations using GLM with binomial distribution for the proportion of cover of soil and rocks, grasses and herbs and shrubs and subshrubs. A GLM with Gamma distribution was used for comparing vegetation mean height. Local variation of precipitation was evaluated using Pearson correlation coefficients. The correlation of monthly precipitations across experimental sites was analyzed by Pearson correlation pairwised between all the sites.

All analyses and plots were performed using R (RCore-Team 2019) and the packages: survival (Therneau 2015), survminer (Kassambara et al. 2019), ggplot2 (Wickham 2016), reshape2 (Wickham 2007) and plyr (Wickham 2011).

\section{Results}

\section{Laboratory germination experiment}

Germination percentage of seeds maintained under laboratory conditions was $79 \%(\mathrm{SE}=0.52 ; \mathrm{n}=5)$ and average germination time 20.83 days $(\mathrm{SE}=1.33$ ).

\section{Irrigated experiment}

Twenty-four seedlings emerged in the control site during the irrigation experiment, from a total of 200 seeds that were sown. Emergence occurred in three of the five plots between 51 (late May) and 95 days (early July) after sowing, leading to a general final emergence percentage of $12 \% \quad(\mathrm{SE}=7.39)$. The plots received an average irrigation of $34.02 \mathrm{~mm}$, with a maximum value of 80.12 and a minimum of 0 (Table S1 supplementary material). All emerged seedlings died during the experiment with a median survival time of 49 days. Along the whole time of emergence in the control site, the environment was characterized by a $100 \%$ of soil cover of grasses and herbs with an average height of $6.96 \mathrm{~cm}(\mathrm{SE}=0.76)$.

\section{Field experiment}

The vegetation cover at the different sites did not show a marked temporal variation for all cover types (coefficients of variation across dates were low for most of the cases, third quartile $=72.5 \%$, Table S2 supplementary material). Therefore, an average value was calculated to characterize each site. In general terms, vegetation cover was dominated by grasses and herbs and tended to be lower at the northeastern 
hillside, with a higher proportion of rocks and bare soil with respect to the southwestern side (GLM, Likelihood Ratio Tests, $p<0.05$, Table 1). Shrubs and subshrubs cover did not differ significantly between altitudes and orientations (GLM Likelihood Ratio Test, Deviance $=4.32, p=0.12$ ). The height of the vegetation showed a peak during the summer months in all the plots. Vegetation tended to be higher at low and mid altitudes of the southwestern hill-side with respect to the northeast side. Minimum values were recorded at the highest sites, regardless of orientation (Fig. 1).

Monthly precipitation across experimental sites ranged from 0 to $140 \mathrm{~mm}$ with an average of $39.2 \mathrm{~mm}$ ( $\mathrm{SE}=0.14, \mathrm{n}=246$ ), during the first year of the experiment (April 2018-March 2019). This was the year in which the entire emergency occurred and therefore this is the precipitation value considered for the analysis. It has to be noted that rainfall during these months was below the average at the reserve for 2000-2016 (670.4 mm vs. $942.2 \mathrm{~mm}$ ). The accumulated rainfall during the summer months (December, January, February) was $129.7 \mathrm{~mm}$, a $43.7 \%$ of the historical average for those months $(296.8 \mathrm{~mm})$. The precipitation curve across the dates showed a high correlation among sites (all the pairwise correlation coefficients between sites were highly significant and ranged between 0.947 and 0.996 , with an average of 0.976, $\mathrm{SE}=0.0002, \mathrm{n}=66$; Fig. 2).

Field experiment—emergence

From a total of 2400 seeds sown in the field, 476 seedlings emerged during the first year $(19.8 \%$ overall emergence) between 33 (early May) and 302 days (late January) after sowing. Only two seedlings emerged during the second season $(0.08 \%$ overall emergence), both 363 days after sowing (late March). The results shown below correspond to the emergence during the first year. The final emergence percentage at each site ranged from $3.5 \%(\mathrm{SE}=1.2 \%)$ to $44.5 \%$ $(\mathrm{SE}=2.4 \%)$ and varied significantly with site orientation and altitude (Tables 2, 3).

All Cox regressions were run with a frailty term for Site and Plot, showing significant effects on the parameter estimates. This is evidence of significant variation in seedling emergence rate with location. The effect of topographic variables on emergence was significant and strong as indicated by the hazard functions (Table 3). Emergence in sites located in southwest hillside was lower and took more time than in sites at the northeast hillsides, as indicated by the lower hazard function for emergence (single model, southwest orientation HR 0.318, CI [0.195-0.519], $p<0.001)$. The effect of altitude showed a significant interaction with slope orientation. At the northeast hillside, sites at mid and high altitude showed a lower hazard function for emergence than those at low altitude (0.48 and 0.36 times, respectively). At the southwest slope, on the contrary, the mid and upper altitude sites were associated with higher hazard functions with respect to those at the lowest altitude $($ HR 6.488/0.081 = 80.1 and HR 8.419/0.081 = 103.9 times, respectively Table 3, Fig. 3).

Table 1 Mean cover of vegetation according to hillside orientation and altitude in Ventania Mountain grasslands, Argentina

\begin{tabular}{llllllll}
\hline Orientation & Altitude & $\begin{array}{l}\text { Shrubs and subshrubs mean cover } \\
(\%)\end{array}$ & $\begin{array}{l}\text { Grasses and herbs mean cover } \\
(\%)\end{array}$ & $\begin{array}{l}\text { Rocks and bare soil mean cover } \\
(\%)\end{array}$ \\
\hline NE & Low & 12.6 & $(0.053)$ & $65.68^{\mathrm{a}}$ & $(0.167)$ & $21.45^{\mathrm{c}}$ & $(0.153)$ \\
$\mathrm{NE}$ & Mid & 10.1 & $(0.085)$ & $70.60^{\mathrm{ab}}$ & $(0.156)$ & $19.35^{\mathrm{bc}}$ & $(0.140)$ \\
$\mathrm{NE}$ & High & 6 & $(0.046)$ & $85.90^{\mathrm{b}}$ & $(0.132)$ & $7.8^{\mathrm{ac}}$ & $(0.103)$ \\
$\mathrm{SW}$ & Low & 12.5 & $(0.098)$ & $84.55^{\mathrm{b}}$ & $(0.117)$ & $2.55^{\mathrm{a}}$ & $(0.061)$ \\
SW & Mid & 13 & $(0.064)$ & $76.50^{\mathrm{ab}}$ & $(0.099)$ & $10.5^{\mathrm{ac}}$ & $(0.079)$ \\
$\mathrm{SW}$ & High & 7.60 & $(0.058)$ & $87.05^{\mathrm{b}}$ & $(0.064)$ & $5.4^{\mathrm{ab}}$ & $(0.054)$ \\
\hline
\end{tabular}

Superscript letters indicate the results of post hoc Tukey tests on GLM binomial model with orientation and altitude as explanatory variables. Categories with the same letter do not differ significantly $(p=0.05)$ 
Fig. 1 Mean height of vegetation in different altitude and hillside orientation in Ventania Mountain grasslands, Argentina

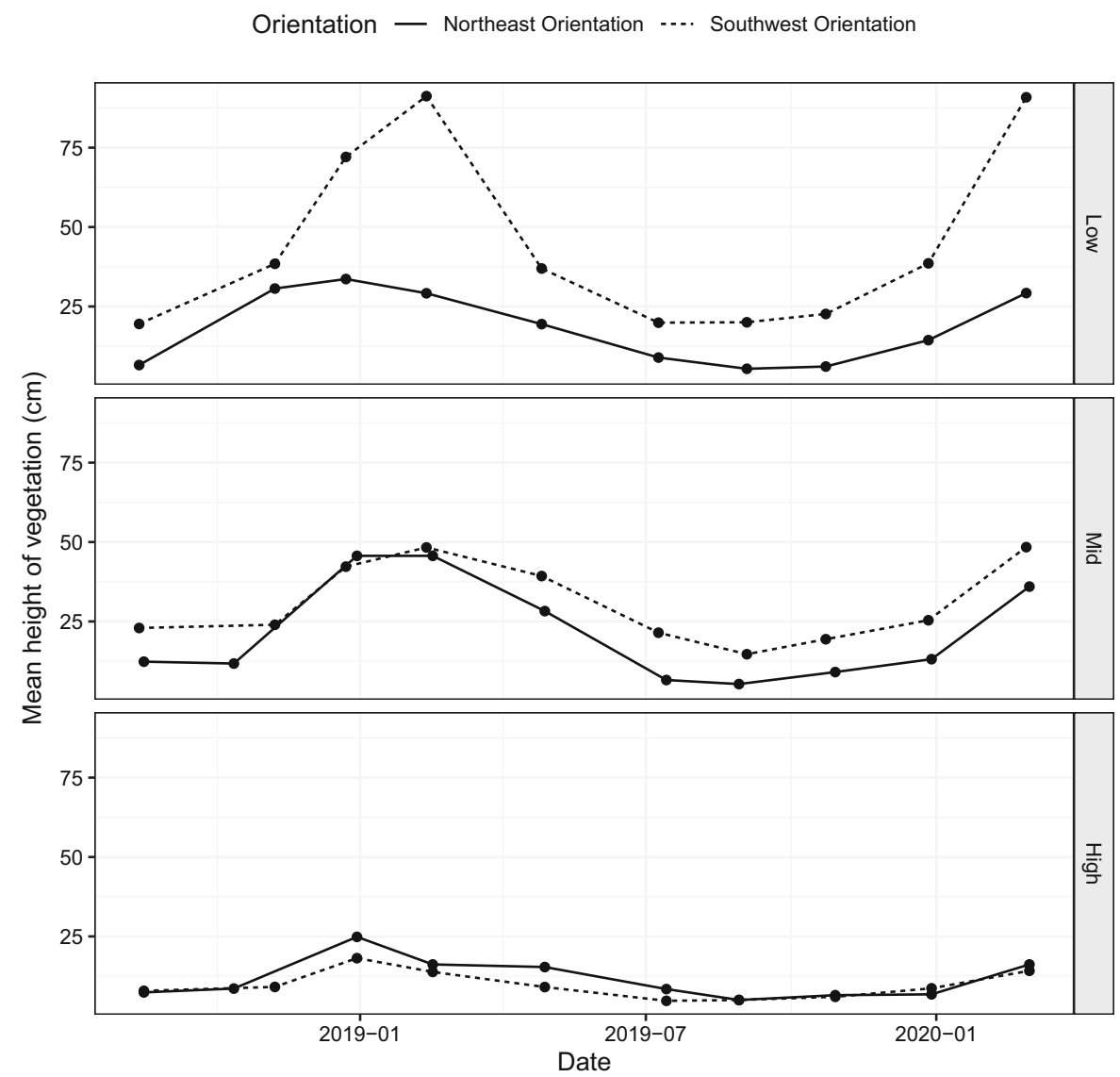

Field experiment—survival

From a total of 476 emerged seedlings, 32 survived after a total of 699 days since sowing $(6.7 \%$ overall survival). Seedling mortality occurred between 13 and 499 days (June 2018 to December 2019) since emergence $($ overall median $=140$ days, January 2019). A high proportion of mortality occurred during the early summer (41\% of the seedlings died in January and mid- February). The final survival percentage at each site ranged from 0 to $34.4 \%(\mathrm{SE}=6.4 \%)$ and varied significantly with site orientation and altitude (Table 2). Survival after ca. 1 year of experiment was estimated at 0.105 (CI 95\% [0.08-0.14]). All Cox regressions were run with a frailty term for Site and Plot, showing significant effects on the parameter estimates. This is evidence of significant variation in seedling survival between different locations. The values of VIF were below five, showing no evidence of collinearity between covariates. The effect of topographic variables on survival was significant, as indicated by the hazard functions (Table 4). Seedling survival showed very different patterns depending on orientation and altitude of the site, denoting an interaction between the effects of both habitat variables. All sites facing to the northeast showed null or very low (below 5\%) seedling survival at the end of the experiment, whereas survival on the opposite side of the mountains reached higher values (34.4\%, Table 2). Highest sites on the northeast hillside showed a steeper decay in survival (median survival at 106 days) compared to those at low and mid altitudes (median survival at 190 and 200 days, respectively, Table 2, Fig. 4). Survival curves decayed faster in sites on the southwest slope (median survival of 64, 106 and 141 days), with higher survival in mid altitudes at the end of the experiment $(34.4 \%$, Table 2, Fig. 4). Mid and upper altitude sites at the southwest hillside showed a lower hazard function than those at the lowest altitude (HR 0.156/ $3.361=0.046$, and HR 0.214/3.361 $=0.064$, respectively), leading to a much slower fall of the survival 
Fig. 2 Monthly precipitation in each plot at different altitude and hillside orientation in Ventania Mountain grasslands, Argentina. Black dots and grey lines indicate precipitation at each experimental site, black line represents the overall average. Interruption of the grey lines indicate missing values for that period, black line was interpolated

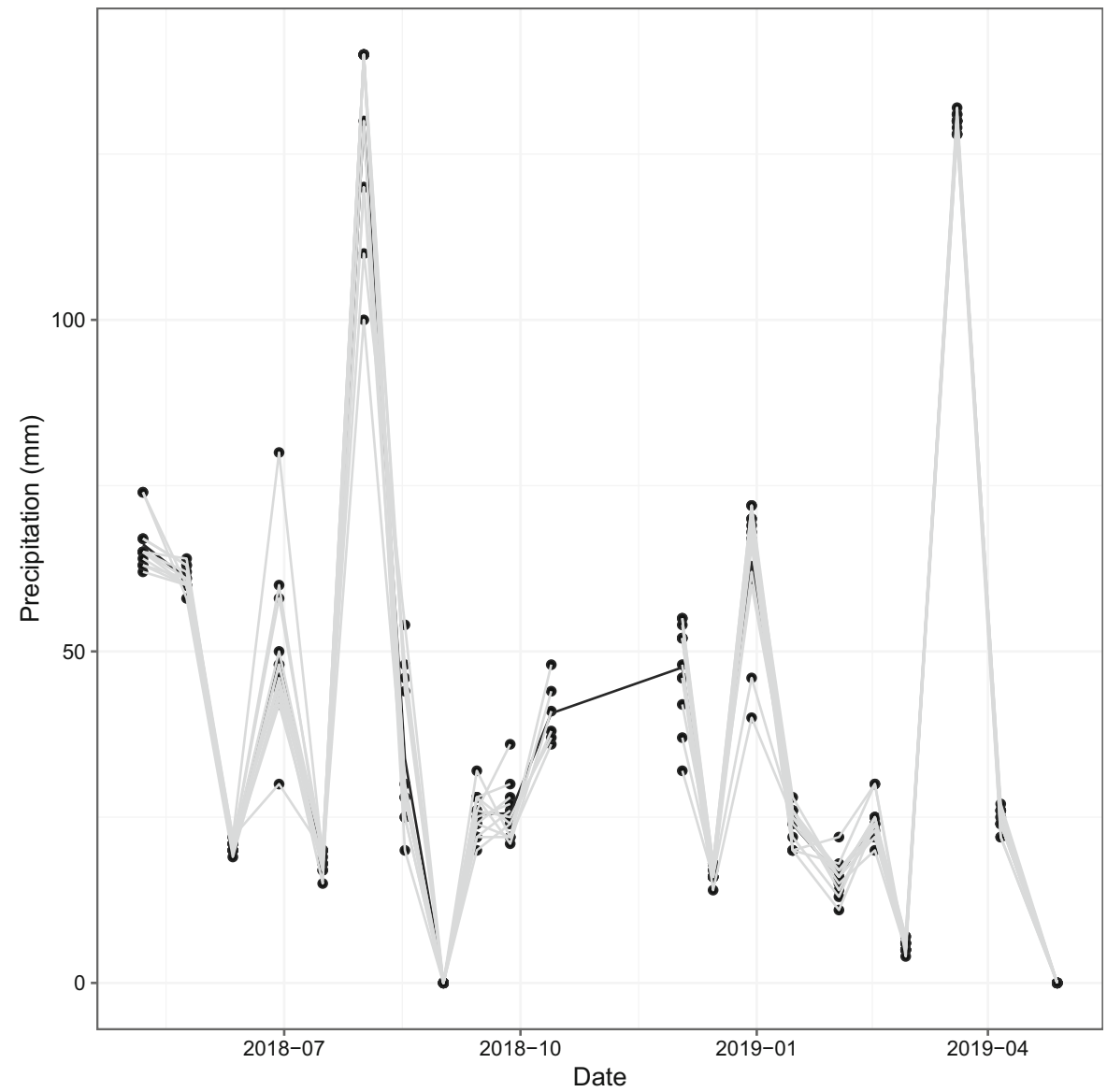

Table 2 Mean emergence and survival percentages of Aleppo pine seedlings germinated from seeds sown under different conditions of hillside orientation and altitude in Ventania Mountain grasslands, Argentina

\begin{tabular}{|c|c|c|c|c|c|c|c|}
\hline \multirow[b]{2}{*}{ Control site } & \multicolumn{2}{|c|}{$\begin{array}{l}\text { Final } \\
\text { emergence } \\
\text { percentage }\end{array}$} & \multirow{2}{*}{$\begin{array}{l}\text { Number of plots } \\
(\mathrm{n}=40)\end{array}$} & \multicolumn{2}{|c|}{$\begin{array}{l}\text { Final } \\
\text { survival } \\
\text { percentage }\end{array}$} & \multirow{2}{*}{$\begin{array}{l}\text { Number of seedlings } \\
\text { at start } \\
24\end{array}$} & \multirow{2}{*}{$\begin{array}{l}\text { Median time of } \\
\text { mortality (days) }\end{array}$} \\
\hline & 12 & (7.39) & & 0 & - & & \\
\hline $\begin{array}{l}\text { Northeast orientation-Low } \\
\text { altitude }\end{array}$ & 42.25 & $(5.01)$ & 10 & 0.59 & $(0.59)$ & 169 & 190 \\
\hline $\begin{array}{l}\text { Northeast orientation-Mid } \\
\text { altitude }\end{array}$ & 23.5 & $(8.96)$ & 10 & 4.26 & (2.1) & 94 & 200 \\
\hline $\begin{array}{l}\text { Northeast orientation- } \\
\text { High altitude }\end{array}$ & 19.25 & $(6.12)$ & 10 & 0 & - & 77 & 106 \\
\hline $\begin{array}{l}\text { Southwest orientation- } \\
\text { Low altitude }\end{array}$ & 5 & (1.49) & 10 & 0 & - & 20 & 64 \\
\hline $\begin{array}{l}\text { Southwest orientation- } \\
\text { Mid altitude }\end{array}$ & 14.75 & $(6.1)$ & 10 & 34.4 & (6.4) & 59 & 141 \\
\hline $\begin{array}{l}\text { Southwest orientation- } \\
\text { High altitude }\end{array}$ & 14.25 & $(5.12)$ & 10 & 8.8 & (3.6) & 57 & 106 \\
\hline
\end{tabular}

Figures between brackets represent the standard error 
Table 3 Emergence rate of Aleppo pine seedlings in Ventania Mountain grasslands, Argentina

\begin{tabular}{llll}
\hline & HR & CI 95\% & $p$ \\
\hline Northeast-Altitude Mid & 0.488 & $(0.222-1.069)$ & $<0.001$ \\
Northeast-Altitude High & 0.366 & $(0.171-0.784)$ & $<0.05$ \\
Southwest-Altitude Low & 0.081 & $(0.037-0.179)$ & $<0.01$ \\
Southwest: Altitude Mid & 6.488 & $(2.074-20.298)$ & $<0.01$ \\
Southwest: Altitude High & 8.419 & $(2.739-25.88)$ & $<0.001$
\end{tabular}

Values are expressed as Hazard Ratio (HR) with 95\% confidence intervals (CI) and $p$ values, as computed from a Cox regression model, using time to germination as time scale, orientation and altitude as interacting covariates and Site-Plot as frailty variable. All HR are expressed with respect to the reference level North Orientation-Altitude Low

curve and resulting in censored seedlings that remained alive at the end of the experiment (Table 4).

Field experiment—seedling growth

The length of 140 days old seedlings varied with orientation and altitude showing no significant interaction between both factors (GLM, interaction term LRT, $p=0.28$ ). The length of seedlings at mid altitudes tended to be higher than in the other altitudes at both sides of the mountain range, with significant differences only at the southwest slope (GLM, Tukey tests, Fig. 5).

\section{Discussion}

This work documents for the first time the effect of topography and local habitat variables on the emergence and establishment of Pinus halepensis in mountain grasslands of the Pampas biome. We found differences in both demographic parameters that could explain variations in the invasive performance of the species and guide management actions aimed at preventing its further expansion in the study area and in other habitats with similar characteristics.

Recruitment capacity in the field has been traditionally identified as a key component of invasive behavior, since it determines colonization ability and population dynamics (Boulant et al. 2008; Steinitz et al. 2011). In spite of the extensive knowledge available regarding this components of the life history for Aleppo pine in its native region (Trabaud et al. 1985; Thanos et al. 1996; Nathan et al. 2000; Nathan and Ne'eman 2004; Omary 2011; Sagra et al. 2019), until this work almost nothing was known about the same components of its population dynamics in
Fig. 3 Cumulative emergence proportion for seedlings of Aleppo pine under different conditions of hillside orientation and altitude. Survival curves are shown (1-Kaplan-Meier curve) with confidence intervals indicated as shaded areas

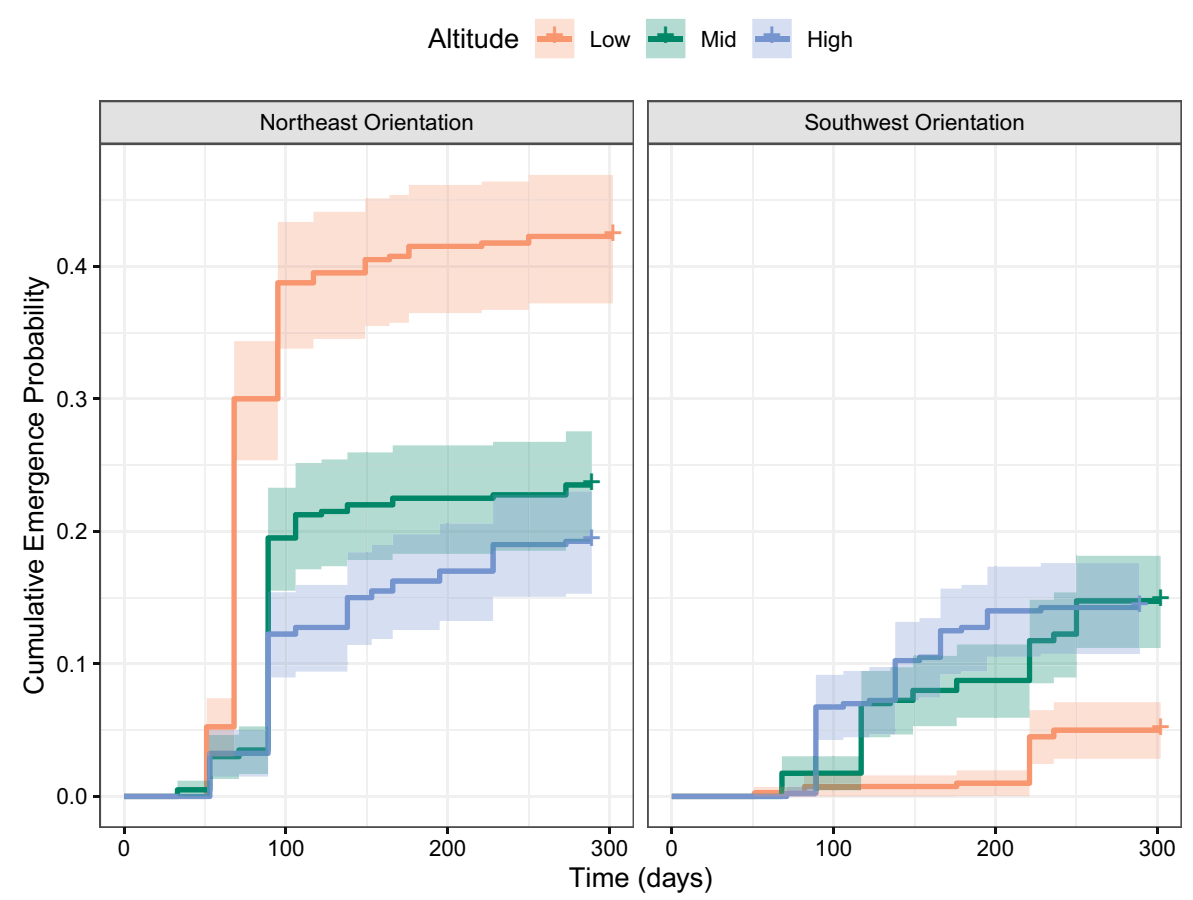


Table 4 Survival rate of Aleppo pine seedlings in Ventania Mountain grasslands, Argentina

\begin{tabular}{lllr}
\hline & HR & CI 95\% & $p$ \\
\hline Northeast-Altitude Mid & 0.904 & $(0.591-1.382)$ & 0.64 \\
Northeast-Altitude High & 1.573 & $(1.017-2.433)$ & $<0.05$ \\
Southwest-Altitude Low & 3.361 & $(1.872-6.034)$ & $<0.001$ \\
Southwest:Altitude Mid & 0.156 & $(0.069-0.349)$ & $<0.001$ \\
Southwest:Altitude High & 0.214 & $(0.098-0.468)$ & $<0.001$ \\
\hline
\end{tabular}

Values are expressed as Hazard Ratio (HR) with 95\% confidence intervals (CI) and $p$ values, as computed from a Cox regression model, using time to germination as time scale, orientation and altitude as interacting covariates and Site-Plot as frailty variable $\left(\chi_{(18.76)}^{2}=35.4, p<0.05\right)$. All HR are expressed with respect to the reference level North Orientation-Altitude Low

invaded ranges (Lavi et al. 2005; de Villalobos et al. 2011; McConnachie et al. 2015).

Our results show an effect of the site on the seedling emergence rate, with topography as a determining factor. As we expected, germination was lower and slower in sites located on the southwest slope of the mountains compared to those on the northeast. During the germination season, NE orientation receives more solar radiation, which determines higher ground temperatures than at the other slopes (Kristensen and
Frangi 1995b). Higher insolation and temperature could favor the emergence of pine trees on these slopes. It was found that long exposure to diurnal light always promotes the germination in $P$. halepensis (Daskalakou and Thanos 1996; Thanos and Daskalakou 2000). This relationship has been also recorded for other pine species, like Pinus sylvestris in the southeast of Spain, where seeds showed a higher germination rate in microhabitats directly exposed to the sun than in shady microhabitats (Castro et al. 2005).

On the contrary, the survival of seedlings once established is lower in sites facing the northeast in our study area. In Aleppo pine the correlation between growth and temperature is usually negative, since higher temperatures result in higher evapotranspiration and reduce water reserves (Condés and GarcíaRobredo 2012). This could be the cause of the highest mortality observed in the NE sites at the study site. Del Campo et al. (2007) report that mild to cold temperature regimes would have improved survival in Aleppo pine plantation in eastern Spain. In regions where this species is native, duration and intensity of the summer drought periods are also the main factors limiting its survival (Broncano et al. 1998; Puértolas et al. 2003; Rathgeber et al. 2005).

Altitude is also recognized as a feature with significant effects on seedling emergence and survival.
Fig. 4 Probability of survival for seedlings of Aleppo pine under different conditions of hillside orientation and altitude in Ventania Mountain grasslands, Argentina. Survival curves (KaplanMeier functions) are shown with confidence intervals indicated as shaded areas. Vertical dashed lines indicate median survival points

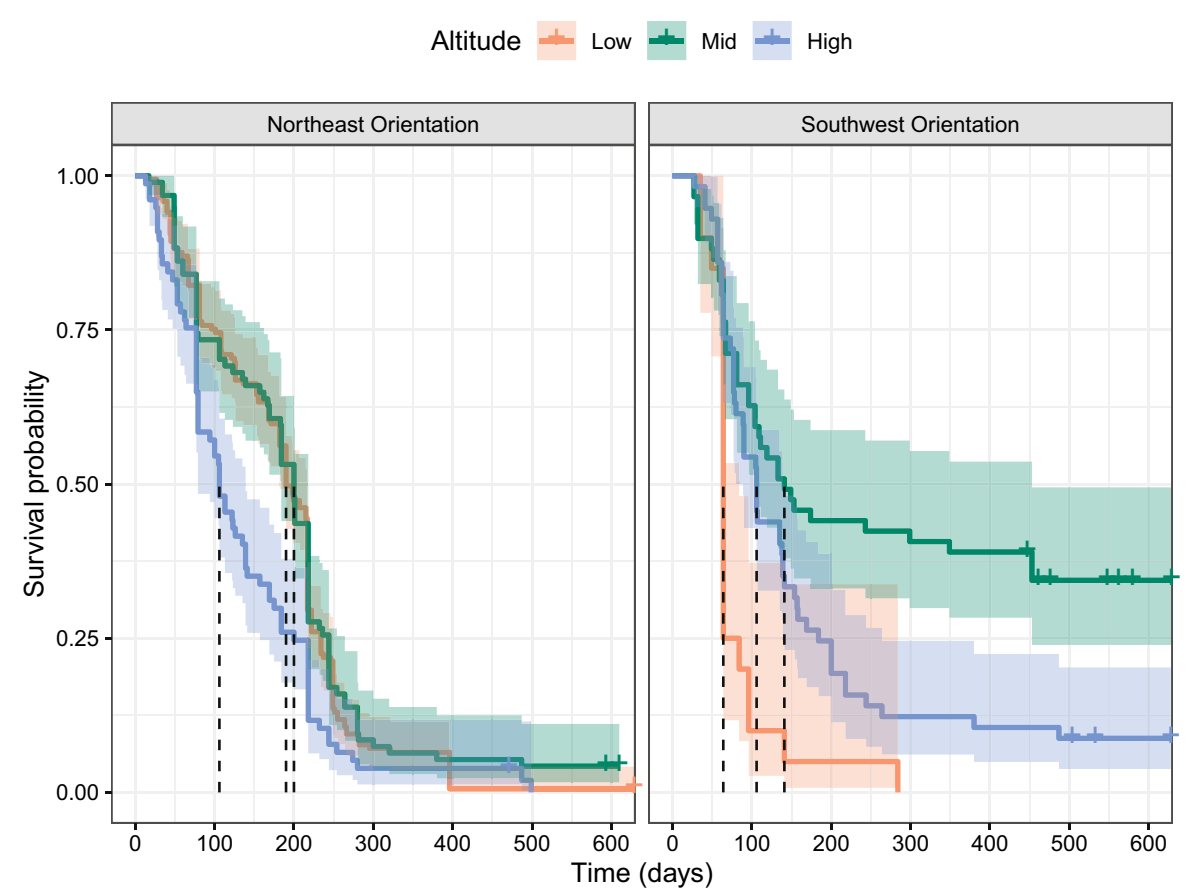


Fig. 5 Average height of seedlings at 140 of sowing (cm). Letters indicate the results or post hoc Tukey tests on GLM Gamma model with orientation and altitude as explanatory variables. Levels with the same letter do not differ $(p=0.05)$

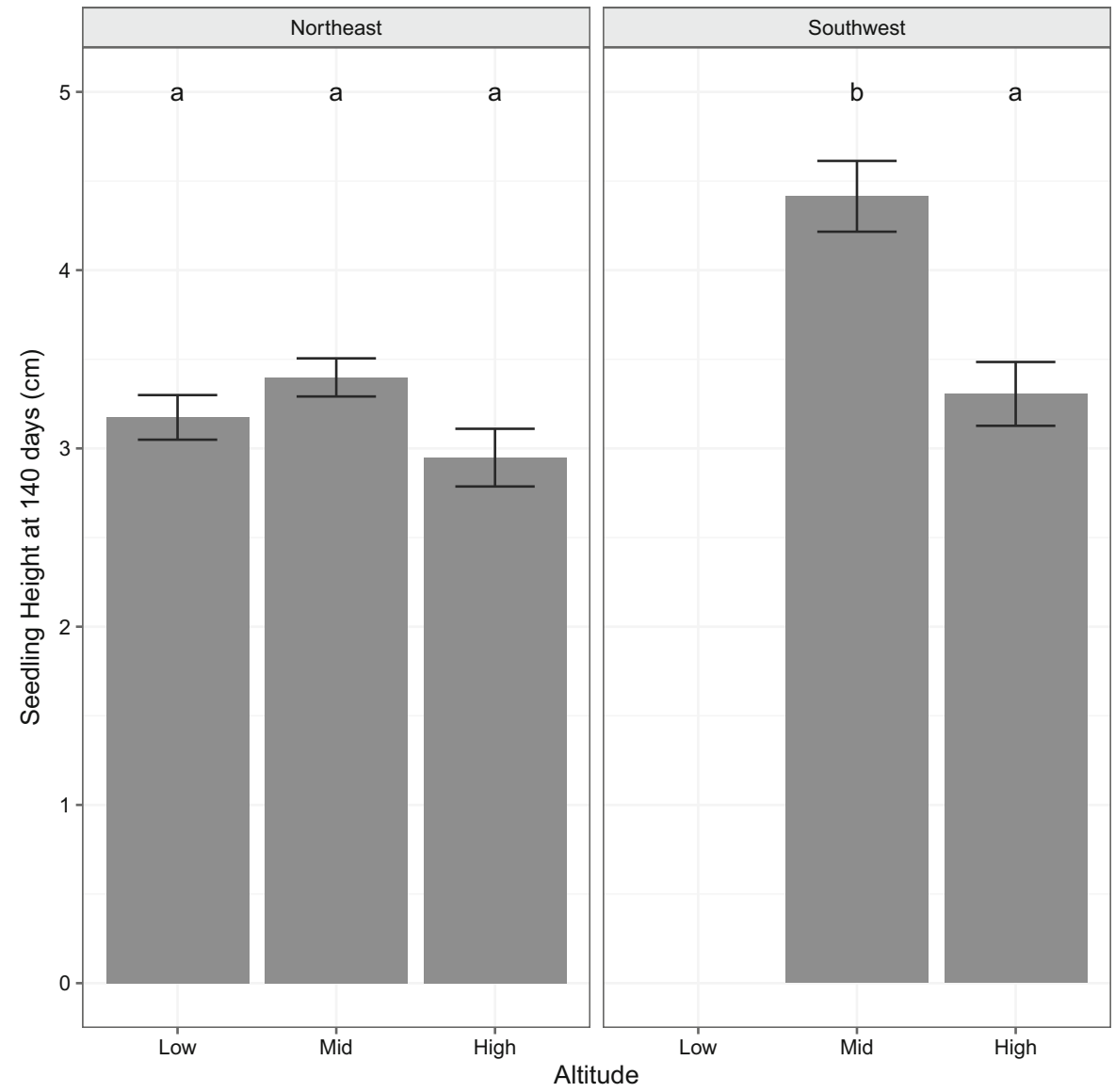

In the Ventania mountains, height seems to have contrasting effects on germination depending on the orientation of the slopes. Thus, while sites located northeast of the mountain range showed less germination at mid and high altitudes (650-950 $\mathrm{m}$ a.s.l.), germination reached its highest values at sites located in the same altitude ranges, but on the southwestern slope. Survival at high and mid altitudes seems to be higher than at low areas. This effect, in turn, is more intense on the southwest slope. These results contradict our expectations of finding lower emergency and establishment on the higher habitats, associated to environmental stressors like low temperatures and stronger winds (Kristensen and Frangi 1995a, 1996). A possible explanation for this discordance could be related to the competition of the seedlings with local vegetation at each site. Basal habitats on the southwest side of the hills are characterized by having the maximum values of plant cover and plant height throughout the year (Table 1). In general terms, pine recruitment is strongly related to interaction between pine seedlings and the resident vegetation. Pines invasion is most prevalent where competition in the regeneration niche is limited, and it occurs more often and intensely in habitats where this trees contrast the most with the dominant vegetation, such as grasslands (Richardson and Bond 1991). Other authors also agree that competition from an abundant herbaceous cover may be responsible for temporal variation in pine recruitment (Rubira et al. 1996; Puértolas et al. 2003; Simberloff et al. 2010; Ayari and Khouja 2014). The effects of vegetation on the emergence and survival of $P$. halepensis seedlings have been already assessed at the study area. De Villalobos et al. (2011) compared the establishment of Aleppo pine under different defoliation regimes of the herbaceous accompanying vegetation. Emergence was almost 50\% higher in areas where vegetation biomass and height were reduced in association with herbivory by feral horses, compared to those under enclosure conditions. They 
argue that herbivory may favor the establishment of pines. Absence or low herbivory intensity can lead to greater cover of grasses and herbs, and a greater resistance to invasion. The characteristics of the vegetation at basal sites on the southwest slope in our study could be similar to those. Conversely, a high grazing intensity causes a decrease in grass cover and greater vulnerability to the establishment of pine seedlings. This is the case at the lower altitude sites on the northeast slope, where the proportion of rocks and bare soil are the highest and probably result in greater availability of microsites appropriate for pine recruitment and reduced competition at the regeneration niche. De Villalobos et al. (2011) report an average seedling survival at 1 year of $16.5 \%$ and $49.7 \%$, in grazing exclusion areas and in areas under grazing of wild horses, respectively. In our study, the overall average survival at 1 year was lower $(10.5 \%)$, which could be due to the variety of habitats considered in the experimental design of our work, including sites under more extreme environmental conditions. The highest survival rate in our trial occurred in the mid altitude sites on the southwest slope, which according to the characteristics of the vegetation could be similar to an intermediate grazing situation. The establishment of $P$. halepensis seedlings could also be affected by the seasonality of grazing in the study area (de Villalobos and Schwerdt 2020). They found that the defoliation of perennial grasses during autumn-winter generates loss of vigor in them, reducing competition at the time of emergence of pine seedlings. This process could facilitate the establishment of this and other invasive species. In our study, however, there are no seasonal differences in vegetation cover. So the emergence and differential survival found could not be explained by this process.

Water availability is recognized as a determining factor for the germination and establishment of Aleppo pine in its native range (Rathgeber et al. 2005; Olivar et al. 2012, 2014; Bueis et al. 2017). Although there are some studies that found variations in rainfall at the local scale at our study area (Frangi and Botinno 1995; Gentili and Gil 2013), our experiments did not detect significant differences among experimental sites. The year in which the test was conducted was not typical in terms of rainfall. Precipitation records showed a water deficit in comparison to the historical records, especially during the summer. In our control site, however, where water stress was avoided through irrigation, both emergence and survival were among the lowest of all sites. This could be indicating the importance of other factors such as microhabitat conditions and the interaction with the surrounding vegetation at the local level. In this regard it is important to understand that the rain, by itself, is not enough to reflect the availability of water for the seedlings. Evapotranspiration, competition and physical parameters of the soil also play a role in this regard (Bueis et al. 2017; Helluy et al. 2020). Potential evapotranspiration, which depends on the net radiation and on temperature, reduces water reserves available to the vegetation (Rathgeber et al. 2005). The lower seedling survival we found at northeast hillside is in concordance with this idea and could be explained by solar exposure. The amount of water that is actually available to plant roots is also strongly related to the properties of the soil and its retention capacity (Bueis et al. 2017). Del Río et al. (2014) found that sites with clay soils presented higher growth rates of $P$. halepensis than sites with other soil types. Knowing the effects of the substrate on the performance of Aleppo pines would probably help to better explain the differences found in the recruitment of the species. Competition, on the other hand, also influences the availability of resources, and may cause differences in the individual growth of plants (Calama et al. 2019). As mentioned before, our results regarding vegetation cover and height are indicative that the competition with the surrounding vegetation can be crucial for recruitment.

Beyond improving knowledge about the relationship between the population dynamics of the species under study and the environmental variables of the areas it colonizes, our results allow adjusting and optimizing the efficiency of management actions aimed at reducing its current and potential effects on the grasslands affected by the invasion that are currently on place. According to our results, the sites at mid and high altitudes on the southwest side of the mountain range, would meet the most appropriate conditions for the establishment and survival of $P$. halepensis seedlings, and thus, are particularly prone for the start of new invasion foci in the study area. From this point of view, it is a priority to detect and eliminate trees that act as seed sources with the potential to reach these areas (those growing upwind and above this sites). These activities must be complemented by actions aimed at detecting young 
individuals growing in these environments before they reach their minimum reproductive age (5 years, Cuevas 2010).

Biological invasions are complex processes that challenge the management capacity of protected areas. Our work shows variations in germination and seedling survival in response to the characteristics of the different environments exposed to invasion. This information can be very useful to develop management strategies for the control of Pinus halepensis in order to optimize the available resources and to increase the chances for successful intervention to slow down the spread of the species.

Acknowledgements This work was supported by the National Scientifc and Technical Research Council (CONICET), Argentina and Universidad Nacional del Sur, Bahía Blanca, Argentina. We are grateful to the Ernesto Tornquist Provincial Park rangers and authorities. We also wish to thank to the anonymous reviewers who provided helpful comments on earlier versions of the manuscript.

Author contributions GIEB and SMZ conceived the study; GIEB collected the data; MRA analysed the data. All the authors led the writing of the manuscript and contributed substantially to revisions.

Data availability statement The data sets generated and/or analysed during the current study will be available in the Zenodo repository [https://doi.org/10.5281/zenodo.4282914].

\section{Compliance with ethical standards}

Conflict of interest The authors declare that they have no conflict of interest.

\section{References}

Alexander ME, Dick J, Weyl O, Robinson TB, Richardson DM (2014) Existing and emerging high impact invasive species are characterized by higher functional responses than natives. Biol Let 10:20130946. https://doi.org/10.1098/ rsbl.2013.0946

Amiotti N, Bravo O, Zalba P, Peinemann N (2007) Effect of landscape position on the acidification of loess-derived soils under Pinus radiata. Austral Ecol 32:534-540. https:// doi.org/10.1111/j.1442-9993.2007.01725.x

Amodeo M, Vázquez B, Zalba S (2017) Generalist dispersers promote germination of an alien Fleshy-fruited Tree Invading Natural Grasslands. PLoS ONE 12(2):e0172423. https://doi.org/10.1371/journal.pone.0172423

Andersen GL, Krzywinski K, Ha Gjessing, Pierce RH (2016) Seed viability and germination success of Acacia tortilis along land-use and aridity gradients in the Eastern Sahara. Ecol Evol 6:256-266. https://doi.org/10.1002/ece3.1851

Ayari A, Khouja ML (2014) Ecophysiological variables influencing Aleppo pine seed and cone production: a review. Tree Physiol 34:426-437. https://doi.org/10.1093/ treephys/tpu022

Ayari A, Moya D, Rejeb MN, Ben Mansoura A, Albouchi A, De Las Heras J, Fezzani T, Henchi B (2011) Geographical variation on cone and seed production of natural Pinus halepensis Mill. forests in Tunisia. J Arid Environ 75:403-410. https://doi.org/10.1016/j.jaridenv.2011.01. 001

Baskin CC, Baskin JM (2014) Seeds: ecology, biogeography, and, evolution of dormancy and germination. Elsevier Science. https://books.google.com.ar/books?id=CYOAQAAQBAJ

Bilenca D, Miñarro F (2004) Identificación de áreas valiosas de pastizal en las pampas y campos de Argentina, Uruguay y sur de Brasil. Fundación Vida Silvestre Argentina, Buenos Aires, Argentina

Boulant N, Kunstler G, Rambal S, Lepart J (2008) Seed supply, drought, and grazing determine spatio-temporal patterns of recruitment for native and introduced invasive pines in grasslands. Divers Distrib 14:862-874. https://doi.org/10. 1111/j.1472.4642.2008.00494.x

Brancatelli GIE, Zalba SM (2018) Vector analysis: a tool for preventing the introduction of invasive alien species into protected areas. Nat Conserv 24:43. https://doi.org/10. 3897/natureconservation.24.20607

Brancatelli GIE, Amodeo MR, Cuevas YA, Zalba SM (2020) Invasive pines in Argentinian grasslands: lessons from control operations. Biol Invasions 22:473-484. https://doi. org/10.1007/s10530-019-02103-9

Broncano MJ, Riba M, Retana J (1998) Seed germination and seedling performance of two Mediterranean tree species, holm oak (shape Quercus ilex L.) and Aleppo pine (shape Pinus halepensis Mill.): a multifactor experimental approach. Plant Ecol 138:17-26. https://doi.org/10.1023/ A: 1009784215900

Bueis T, Bravo F, Pando V, Turrión MB (2017) Site factors as predictors for Pinus halepensis Mill. productivity in Spanish plantations. Ann For Sci 74:6. https://doi.org/10. 1007/s13595-016-0609-7

Cabrera AL (1976) Regiones Fitogeográficas Argentinas. In: Parodi LR (ed) Encyclopedia Argentina de Agricultura y Jardinería. Tomo II, Edición Acme, Buenos Aires, Argentina, pp 1-85

Calama R, Conde M, de-Dios-García J, Madrigal G, VázquezPiqué J, Gordo FJ, Pardos M (2019) Linking climate, annual growth and competition in a Mediterranean forest: Pinus pinea in the Spanish Northern Plateau. Agric For Meteorol 264:309-321. https://doi.org/10.1016/j. agrformet.2018.10.017

Castro J, Zamora R, Hodar JA, Gomez JM (2004) Seedling establishment of a boreal tree species (Pinus sylvestris) at its southernmost distribution limit: consequences of being in a marginal Mediterranean habitat. J Ecol 92:266-277. https://doi.org/10.1111/j.0022-0477.2004.00870.x

Castro J, Zamora R, Hodar JA, Gómez JM (2005) Ecology of seed germination of Pinus sylvestris L. at its southern, Mediterranean distribution range. For Syst 14:143-152 
Condés S, García-Robredo F (2012) An empirical mixed model to quantify climate influence on the growth of Pinus halepensis Mill. stands in South-Eastern Spain. For Ecol Manage 284:59-68. https://doi.org/10.1016/j.foreco.2012. 07.030

Cuevas YA (2010) Claves ecológicas para la restauración de un pastizal natural invadido por Pinus halepensis. Tesis de Doctorado. Universidad Nacional del Sur, Bahía Blanca, Buenos Aires, Argentina. http://repositoriodigital.uns.edu. ar/handle/123456789/2150

Daskalakou EN, Thanos CA (1996) Aleppo pine (Pinus halepensis) postfire regeneration: the role of canopy and soil seed banks. Int J Wildland Fire 6:59-66. https://doi. org/10.1071/WF9960059

de Villalobos AE, Schwerdt L (2020) Seasonality of feral horse grazing and invasion of Pinus halepensis in grasslands of the Austral Pampean Mountains (Argentina): management considerations. Biol Invasions 22:2941-2955. https://doi. org/10.1007/s10530-020-02300-x

de Villalobos A, Zalba S (2010) Continuous feral horse grazing and grazing exclusion in mountain pampean grasslands in Argentina. Acta Oecol 36:514-519. https://doi.org/10. 1016/j.actao.2010.07.004

de Villalobos AE, Zalba SM, Peláez DV (2011) Pinus halepensis invasion in mountain pampean grassland: effects of feral horses grazing on seedling establishment. Environ Res 111:953-959. https://doi.org/10.1016/j. envres.2011.03.011

Del Campo AD, Cerrillo RMN, Hermoso J, Ibáñez AJ (2007) Relationships between site and stock quality in Pinus halepensis Mill. reforestation on semiarid landscapes in eastern Spain. Ann For Sci 64:719-731. https://doi.org/10. 1051/forest:2007052

Del Río M, Calama R, Montero G (2008) Selvicultura de Pinus halepensis Mill. Serrada R, Montero G, Reque JA (eds) Compendio de Selvicultura Aplicada En España. INIAFUCOVASA, Madrid, pp 289-312

Del Río M, Rodríguez-Alonso J, Bravo-Oviedo A, Ruíz-Peinado R, Cañellas I, Gutiérrez E (2014) Aleppo pine vulnerability to climate stress is independent of site productivity of forest stands in southeastern Spain. Trees 28:1209-1224. https://doi.org/10.1007/s00468-014-10310

Dickie IA, St John MG, Yeates GW, Morse CW, Bonner KI, Orwin K, Peltzer DA (2014) Belowground legacies of Pinus contorta invasion and removal result in multiple mechanisms of invasional meltdown. AoB PLANTS. https://doi.org/10.1093/aobpla/plu056

Eriksson O, Ehrlén J (1992) Seed and microsite limitation of recruitment in plant populations. Oecologia 91:360-364. https://doi.org/10.1007/BF00317624

Fonseca CR, Guadagnin DL, Emer C, Masciadri S, Germain P, Zalba SM (2013) Invasive alien plants in the Pampas grasslands: a tri-national cooperation challenge. Biol Invasions 15:1751-1763. https://doi.org/10.1007/s10530013-0406-2

Frangi JL, Botinno OJ (1995) Comunidades vegetales de la Sierra de la Ventana, provincia de Buenos Aires, Argentina. Revista de La Facultad de Agronomía, La Plata 71:93-133
Gasque M, García-Fayos P (2004) Interaction between Stipa tenacissima and Pinus halepensis: consequences for reforestation and the dynamics of grass steppes in semiarid Mediterranean areas. For Ecol Manage 189:251-261. https://doi.org/10.1016/j.foreco.2003.08.014

Gentili JO, Gil V (2013) Variabilidad temporal de las precipitaciones en vertientes opuestas del Sistema de Ventania, Buenos Aires, Argentina. Revista Universitaria de Geografía 22:147-166

Gorgens A, Van Wilgen B (2004) Invasive alien plants and water resources in South Africa: current understanding, predictive ability and research challenges: Working for Water. South African J Sci 100:27-33. http://hdl.handle. net/10204/761

Harper JL (1977) Population biology of plants. Academic Press, New York

Helluy M, Prévosto B, Cailleret M, Fernandez C, Balandier P (2020) Competition and water stress indices as predictors of Pinus halepensis Mill. radial growth under drought. For Ecol Manage. https://doi.org/10.1016/j.foreco.2020. 117877

Jobbágy EG, Jackson RB (2003) Patterns and mechanisms of soil acidification in the conversion of grasslands to forests. Biogeochemistry 64:205-229. https://doi.org/10.1023/A: 1024985629259

Jobbágy EG, Acosta AM, Nosetto MD (2013) Rendimiento hídrico en cuencas primarias bajo pastizales y plantaciones de pino de las sierras de Córdoba (Argentina). Ecología Austral 23:87-96. http://hdl.handle.net/10625/54821

Kassambara A, Kosinski A, Biecek P, Fabian S (2019) Survminer: drawing survival curves using'ggplot2'. 2019. R Package Version 0.44

Kristensen MJ, Frangi JL (1995a) La Sierra de la Ventana: una isla de biodiversidad. Ciencia Hoy 5:25-34

Kristensen MJ, Frangi JL (1995b) Mesoclimas de pastizales de la Sierra de la Ventana. Ecología Austral 5:55-64

Kristensen MJ, Frangi JL (1996) Mesoclimas de roquedales de la Sierra de la Ventana. Ecología Austral 6:115-122

Langdon B, Cavieres LA, Pauchard A (2019) At a microsite scale, native vegetation determines spatial patterns and survival of Pinus contorta invasion in Patagonia. Forests 10(8):654. https://doi.org/10.3390/f10080654

Lavi A, Perevolotsky A, Kigel J, Noy-Meir I, Hermy M (2005) Invasion of Pinus halepensis from plantations into adjacent natural habitats. Appl Veg Sci 8:85-92. https://doi.org/10. 1658/1402-2001(2005)008\%5b0085:IOPHFP\%5d2.0. $\mathrm{CO} ; 2$

Long MA, Peter G, Villamil CB (2004) La familia Asteraceae en el sistema de Ventania (Buenos Aires, Argentina). Boletín Sociedad Argentina de Botánica 39:159-169

Lövei GL, Lewinsohn TM (2012) Megadiverse developing countries face huge risks from invasives. Trends Ecol Evol 27:2-3. https://doi.org/10.1016/j.tree.2011.10.009

Manso R, Fortin M, Calama R, Pardos M (2013) Modelling seed germination in forest tree species through survival analysis. The Pinus pinea L. case study. For Ecol Manage 289:515-524. https://doi.org/10.1016/j.foreco.2012.10. 028

Mast JN, Veblen TT, Hodgson ME (1997) Tree invasion within a pine/grassland ecotone: an approach with historic aerial photography and GIS modeling. For Ecol Manage 
93:181-194. 1127(96)03954-0

https://doi.org/10.1016/S0378-

McConnachie MM, van Wilgen BW, Richardson DM, Ferraro PJ, Forsyth AT (2015) Estimating the effect of plantations on pine invasions in protected areas: a case study from South Africa. J Appl Ecol 52:110-118. https://doi.org/10. 1111/1365-2664.12366

McNair JN, Sunkara A, Frobish D (2012) How to analyse seed germination data using statistical time-to-event analysis: non-parametric and semi-parametric methods. Seed Sci Res 22:77-95. https://doi.org/10.1017/ S0960258511000547

Nathan R, Ne'eman G (2004) Spatiotemporal dynamics of recruitment in Aleppo pine (Pinus halepensis Miller). Plant Ecol 171:123-137. https://doi.org/10.1023/B:VEGE. 0000029379.32705.0f

Nathan R, Safriel UN, Noy-Meir I, Schiller G (2000) Spatiotemporal variation in seed dispersal and recruitment near and far from Pinus halepensis trees. Ecology 81:2156-2169. https://doi.org/10.1890/00129658(2000)081\%5b2156:SVISDA\%5d2.0.CO;2

Olivar J, Bogino S, Spiecker H, Bravo F (2012) Climate impact on growth dynamic and intra-annual density fluctuations in Aleppo pine (Pinus halepensis) trees of different crown classes. Dendrochronologia 30:35-47. https://doi.org/10. 1016/j.dendro.2011.06.001

Olivar J, Bogino S, Rathgeber C, Bonnesoeur V, Bravo F (2014) Thinning has a positive effect on growth dynamics and growth-climate relationships in Aleppo pine (Pinus halepensis) trees of different crown classes. Ann For Sci 71:395-404. https://doi.org/10.1007/s13595-013-0348-y

Omary AA (2011) Effects of aspect and slope position on growth and nutritional status of planted Aleppo pine (Pinus halepensis Miller) in a degraded land semi-arid areas of Jordan. New For 42:285-300. https://doi.org/10.1007/ s11056-011-9251-2

Papadopoulos A, Tolica K, Pantera A, Maheras P (2009) Investigation of the annual variability of the Aleppo pine tree-ring width: the relationship with the climatic conditions in the Attica basin. Glob Nest J 11:583-592

Parodi LR (1942) ¿Por qué no existen bosques naturales en la llanura bonaerense? Revista del Centro de Estudiantes de la Facultad de Agronomía de la Universidad Nacional de Buenos Aires 30:387-390

Pretelli MG, Isacch JP, Cardoni DA (2015) Effects of fragmentation and landscape matrix on the nesting success of grassland birds in the Pampas grasslands of Argentina. Ibis 157:688-699. https://doi.org/10.1111/ibi.12292

Puértolas J, Gil L, Pardos JA (2003) Effects of nutritional status and seedling size on field performance of Pinus halepensis planted on former arable land in the Mediterranean basin. Forestry 76:159-168. https://doi.org/10.1093/forestry/76. 2.159

R Core Team (2019) R: A language and environment for statistical computing. R Foundation for Statistical Computing, Vienna, Austria. https://www.R-project.org/

Rathgeber CBK, Misson L, Nicault A, Guiot J (2005) Bioclimatic model of tree radial growth: application to the French Mediterranean Aleppo pine forests. Trees 19:162-176. https://doi.org/10.1007/s00468-004-0378-z
Retana J, Espelta JM, Gracia M, Riba M (1999) Seedling recruitment. In: Rodà F, Retana J, Gracia CA, Bellot J (eds) Ecology of Mediterranean evergreen oak forests. Springer, Berlin Heidelberg, pp 89-103

Richardson DM (1998) Forestry trees as invasive aliens. Conserv Biol 12:18-26. https://doi.org/10.1111/j.1523-1739. 1998.96392.x

Richardson DM and Bond WJ (1991) Determinants of plant distribution: evidence from Pine invasions. Am Nat 137:639-668. www.jstor.org/stable/2462600

Richardson DM, Higgins SI (2000) Pines as invaders in the southern hemisphere. In: Richardson DM (ed) Ecology and biogeography of pinus. Cambridge University Press, Cambridge, pp 450-470

Richardson DM, Rundel PW (1998) Ecology and biogeography of Pinus: an introduction. In: Richardson DM (ed) Ecology and biogeography of Pinus. Cambridge University Press, Cambridge, pp 3-49

Rubira JLP, Bueno LO, Lerena SD, Estrada IR (1996) Experiencias sobre control de la competencia herbácea en repoblaciones de terrenos agrícolas abandonados. Resultados de tres años en campo. Montes 45:30-36

Sagra J, Moya D, Plaza-Álvarez P, Lucas-Borja M, GonzálezRomero J, De las Heras J, Alfaro-Sánchez R, Ferrandis P (2019) Prescribed fire effects on early recruitment of Mediterranean pine species depend on fire exposure and seed provenance. For Ecol Manage 441:253-261. https:// doi.org/10.1016/j.foreco.2019.03.057

Simberloff D, Nuñez MA, Ledgard NJ, Pauchard A, Richardson DM, Sarasola M et al (2010) Spread and impact of introduced conifers in South America: lessons from other southern hemisphere regions. Austral Ecol 35:489-504. https://doi.org/10.1111/j.1442-9993.2009.02058.x

Simberloff D, Martin JL, Genovesi P, Maris V, Wardle DA, Aronson $\mathrm{J}$ et al (2013) Impacts of biological invasions: what's what and the way forward. Trends Ecol Evol 28:58-66. https://doi.org/10.1016/j.tree.2012.07.013

Skordilis A, Thanos C (1995) Seed stratification and germination strategy in the Mediterranean pines Pinus brutia and $P$. halepensis. Seed Sci Res 5:151-160

Skordilis A, Thanos CA (1997) Comparative ecophysiology of seed germination strategies in the seven pine species naturally growing in Greece. In: Ellis RH, Black M, Murdoch AJ, Hong TD (eds) Basic and applied aspects of seed biology. Springer, Netherlands, pp 623-632

Steinitz O, Troupin D, Vendramin G, Nathan R (2011) Genetic evidence for a Janzen-Connell recruitment pattern in reproductive offspring of Pinus halepensis trees. Mol Ecol 20:4152-4164. https://doi.org/10.1111/j.1365-294X.2011. 05203.x

Taylor KT, Maxwell BD, McWethy DB, Pauchard A, Nuñez MA, Whitlock C (2017) Pinus contorta invasions increase wildfire fuel loads and may create a positive feedback with fire. Ecology 98:678-687. https://doi.org/10.1002/ecy. 1673

Thanos CA, Daskalakou EN (2000) Reproduction in Pinus halepensis and Pinus brutia. In: Ne'eman G, Trabaud L (eds) Ecology, biogeography and management of Pinus halepensis and $P$. brutia forest ecosystems in the Mediterranean Basin. Backhuys Publishers, Leiden, pp 79-90 
Thanos CA, Daskalakou EN, Nikolaidou S (1996) Early postfire regeneration of a Pinus halepensis forest on Mount Párnis, Greece. J Veg Sci 7:273-280. https://doi.org/10. 2307/3236328

Therneau T (2015) A package for survival analysis in S. R package version 2.38. http://CRAN.R-project.org/ package $=$ survival

Trabaud L, Michels C, Grosman J (1985) Recovery of burnt Pinus halepensis Mill. forests. II. Pine reconstruction after wildfire. For Ecol Manage 13:167-179. https://doi.org/10. 1016/0378-1127(85)90032-5

Turnbull LA, Crawley MJ, Rees M (2000) Are plant populations seed-limited? A review of seed sowing experiments. Oikos 88:225-238. https://doi.org/10.1034/j.1600-0706.2000. 880201.x

Vennetier M, Ripert C, Rathgeber C (2018) Autecology and growth of Aleppo pine (Pinus halepensis Mill.): a comprehensive study in France. For Ecol Manage 413:32-47. https://doi.org/10.1016/j.foreco.2018.01.028

Wickham H (2007) Reshaping data with the reshape package. J Stat Softw 21:1-20

Wickham H (2011) The split-apply-combine strategy for data analysis. J Stat Softw 40:1-29
Wickham H (2016) ggplot2: elegant graphics for data analysis. Springer, NewYork

Williams MC, Wardle GM (2005) The invasion of two native Eucalypt forests by Pinus radiata in the Blue Mountains, New South Wales, Australia. Biol Conserv 125:55-64. https://doi.org/10.1016/j.biocon.2005.03.011

Yezzi AL, Nebbia AJ, Zalba SM (2018) Fragmentación de pastizales psamófilos por plantaciones de pinos: efectos sobre la riqueza y la composición vegetal. Ecología Austral 28:133-144. https://doi.org/10.25260/EA.18.28.1.0.640

Zalba SM, Villamil CB (2002) Woody plant invasion in Relictual Grasslands. Biol Invasion 4:55-72. https://doi. org/10.1023/A:1020532609792

Zalba SM, Cuevas YA, Boó RM (2008) Invasion of Pinus halepensis Mill. following a wildfire in an Argentine grassland nature reserve. J Environ Manage 88:539-546. https://doi.org/10.1016/j.jenvman.2007.03.018

Publisher's Note Springer Nature remains neutral with regard to jurisdictional claims in published maps and institutional affiliations. 